\section{Pacific Northwest}

National Laboratory

Operated by Battelle for the

U.S. Department of Energy

\title{
The Independent Technical Analysis Process
}

\author{
CA Duberstein \\ DD Dauble \\ KD Ham \\ GE Johnson
}

March 2007

Prepared for the U.S. Department of Energy under Contract DE-AC05-76RL01830 


\title{
DISCLAIMER
}

This report was prepared as an account of work sponsored by an agency of the United States Government. Neither the United States Government nor any agency thereof, nor Battelle Memorial Institute, nor any of their employees, makes any warranty, express or implied, or assumes any legal liability or responsibility for the accuracy, completeness, or usefulness of any information, apparatus, product, or process disclosed, or represents that its use would not infringe privately owned rights. Reference herein to any specific commercial product, process, or service by trade name, trademark, manufacturer, or otherwise does not necessarily constitute or imply its endorsement, recommendation, or favoring by the United States Government or any agency thereof, or Battelle Memorial Institute. The views and opinions of authors expressed herein do not necessarily state or reflect those of the United States Government or any agency thereof.

\author{
PACIFIC NORTHWEST NATIONAL LABORATORY \\ operated by \\ BATTELLE \\ for the \\ UNITED STATES DEPARTMENT OF ENERGY \\ under Contract DE-AC05-76RL01830
}

Printed in the United States of America
Available to DOE and DOE contractors from the Office of Scientific and Technical Information,
P.O. Box 62, Oak Ridge, TN 37831-0062;
ph: (865) 576-8401
fax: $(865)$ 576-5728
email: reports@adonis.osti.gov

\begin{abstract}
Available to the public from the National Technical Information Service, U.S. Department of Commerce, 5285 Port Royal Rd., Springfield, VA 22161 ph: (800) 553-6847 fax: $(703) 605-6900$ email: orders@ntis.fedworld.gov online ordering: http://www.ntis.gov/ordering.htm
\end{abstract}

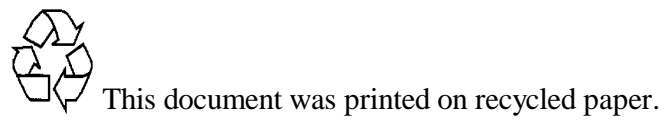




\title{
The Independent Technical Analysis Process
}

\section{Final Report}

\author{
Prepared by \\ Corey A. Duberstein, Kenneth D. Ham, Dennis D. Dauble, Gary E. Johnson \\ Pacific Northwest National Laboratory \\ Richland, Washington
}

Prepared for

U.S. Department of Energy

Bonneville Power Administration

Division of Fish and Wildlife

Portland, Oregon

Project No. 2006-010-00

Contract No. 00000652

\section{March 2007}




\section{Preface}

The Bonneville Power Administration (BPA) contracted with the Pacific Northwest National Laboratory (PNNL) to provide technical analytical support for system-wide fish passage information (BPA Project No. 2006-010-00). The goal of this project was to produce rigorous technical analysis products using independent analysts and anonymous peer reviewers. This project provided an independent technical source for non-routine fish passage analyses while allowing routine support functions to be performed by other well-qualified entities. 


\section{Contents}

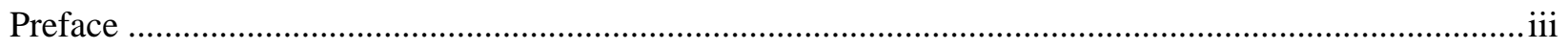

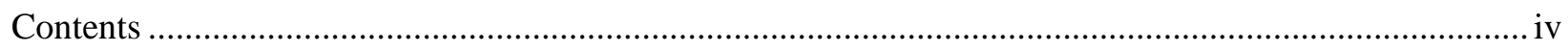

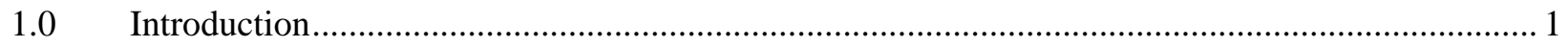

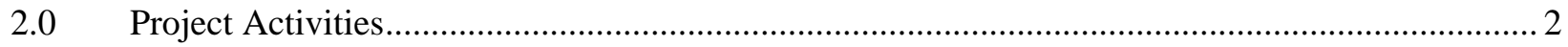

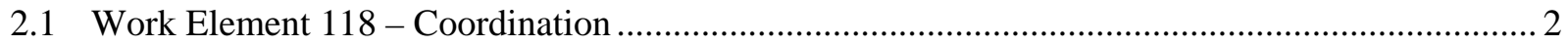

2.2 Work Element 162 - Analyze/Interpret Data ....................................................................... 5

2.3 Work Element 119 - Project Management .................................................................................. 5

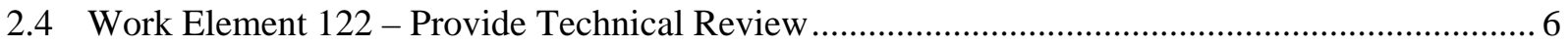

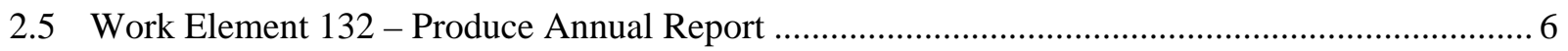

2.6 Work Element 161 - Disseminate Raw/Summary Data and Results .......................................... 7

2.7 Work Element 185 - Produce Pisces Status Report …..................................................... 8

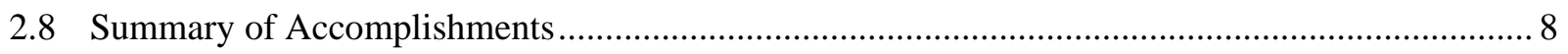




\subsection{Introduction}

The Independent Technical Analysis Process (ITAP) was created to provide non-routine analysis for fish and wildlife agencies and tribes in particular and the public in general on matters related to juvenile and adult salmon and steelhead passage through the mainstem hydrosystem. The process was designed to maintain the independence of analysts and reviewers from parties requesting analyses, to avoid potential bias in technical products.

The objectives identified for this project were to administer a rigorous, transparent process to deliver unbiased technical assistance necessary to coordinate recommendations for storage reservoir and river operations that avoid potential conflicts between anadromous and resident fish.

Seven work elements, designated by numbered categories in the Pisces project tracking system, were created to define and accomplish project goals as follows:

118 Coordination - Coordinate technical analysis and review process:

a. Retain expertise for analyst/reviewer roles.

b. Draft research directives.

c. Send directive to the analyst.

d. Coordinate two independent reviews of the draft report.

e. Ensure reviewer comments are addressed within the final report.

162 Analyze/Interpret Data - Implement the independent aspects of the project.

122 Provide Technical Review - Implement the review process for the analysts.

132 Produce Annual Report - FY06 annual progress report with Pisces Disseminate

161 Disseminate Raw/Summary Data and Results - Post technical products on the ITAP web site.

185-Produce Pisces Status Report - Provide periodic status reports to BPA.

119 Manage and Administer Projects - project/contract administration. 


\subsection{Project Activities}

\subsection{Work Element 118 - Coordination}

To accomplish the goals of the project and also maintain the independent nature of the process, we identified individuals with the relevant expertise to both analyze data to address research questions and to review the resulting reports. Individuals recognized within the region for experience in fish biology, population dynamics, fish passage and survival, database integration, hydroacoustics, statistics and biometry, hydraulics, fish passage engineering, and ecological monitoring were identified and solicited for participation within the project. Individuals could function as both an analyst and a reviewer if they met the following qualifications:

- undertaken substantial scientific research work in a field related to fish passage in the Columbia River and its management; that work would include a record of publication in peer-reviewed scientific literature

- high standards of scientific integrity, independence, and objectivity

- $\quad$ sufficient time, interest, stature, and breadth to be effective

- experience providing balanced and objective scientific analysis and a demonstrated ability to distinguish between scientific advice and policy recommendations (i.e., professional independence from the agencies that manage and fund fish passage measures (e.g., BPA, National Marine Fisheries Service) and the stakeholders in the water management and environmental protection arenas).

Specific education, expertise, and experience required for the TA position include

- an M.S./PhD. degree in one of the following or related fields: Biology, Ecology, Fisheries, Hydrology, River Geomorphology, Statistics, Wildlife Ecology, Ocean and Estuary Ecology, Fish Husbandry, Genetics, Social and Economic Sciences

- expertise in fish passage, hydrosystem operations, statistical analysis, predator interactions, fish husbandry, genetics, hydrology, or other relevant field

- expertise integrating information from multiple disciplines

- at least 5 years relevant experience

- experience integrating numerous disciplines into a comprehensive analysis of factors influencing fish passage 
- experience providing written and oral reports, making presentations at conferences and workshops, and publishing in scientific journals

- a recognized record of publication in the peer-reviewed scientific literature in the area of expertise requested.

Candidate familiarity with the issues involving fish passage management in the Columbia River hydrosystem also is a desired attribute for TAs.

A Technical Reviewer (TR) must

- Have an M.S./PhD. degree in one of the following or related fields: Biology, Ecology, Fisheries, Hydrology, River Geomorphology, Statistics, Wildlife Ecology, Ocean and Estuary Ecology, Fish Husbandry, Genetics, Social and Economic Sciences.

- Have expertise in fish passage, hydrosystem operations, statistical analysis, predator interactions, fish husbandry, genetics, hydrology, or other relevant field.

- Be an expert at integrating information from multiple disciplines.

- Have at least 5 years relevant experience.

- Have experience integrating numerous disciplines into a comprehensive analysis of factors influencing fish passage.

- Have experience providing written and oral reports, making presentations at conferences workshops, and publishing in scientific journals.

- Have recognized record of publication in the peer reviewed scientific literature in the area of expertise requested.

Candidate familiarity with the issues involving fish passage management in the Columbia River hydrosystem also is a desired attribute for TRs.

Twenty-three individuals (Table 1) were selected and retained under a subcontract as TAs and TRs on an as-needed basis. 
Table 1. Independent Scientists Selected for Analysis and Review of ITAP Products

\begin{tabular}{|c|c|c|c|}
\hline Name & Affiliation & Education & Expertise \\
\hline Beamesderfer, Ray & Cramer Fish Sciences & M.S. & Fish biology and management \\
\hline Coutant, Charles & $\begin{array}{l}\text { Retired from Oak Ridge National } \\
\text { Laboratory }\end{array}$ & Ph.D. & Thermal and water quality effects on aquatic ecology \\
\hline Cramer, Steve & Cramer Fish Sciences & M.S. & $\begin{array}{l}\text { Population dynamics and modeling, effects and survival } \\
\text { analysis }\end{array}$ \\
\hline Fisher, Tim & Cramer Fish Sciences & M.S. & Fish population modeling, data management \\
\hline Giorgi, Al & BioAnalysts, Inc. & Ph.D. & Fish passage, survival, bypass \\
\hline Goodman, Dan & Montana State University & Ph.D. & Biometry, marine fish ecology and management \\
\hline Hillman, Tracey & BioAnalysts, Inc. & Ph.D. & Fish biology, stream ecology, monitoring design \\
\hline Hinrichsen, Richard & Hinrichsen Environmental Services & Ph.D. & $\begin{array}{l}\text { Juvenile salmon migration modeling and survival, salmon } \\
\text { life cycles }\end{array}$ \\
\hline Jager, Henriette & Oak Ridge National Laboratory & Ph.D. & Ecological modeling \\
\hline Johnson, Peter & $\begin{array}{l}\text { LGL Limited, Environmental } \\
\text { Research Associates }\end{array}$ & M.S. & Hydroacoustics and fish passage \\
\hline $\begin{array}{l}\text { McConnaha, Willis } \\
\text { (Chip) }\end{array}$ & Jones \& Stokes & Ph.D. & Hydroelectric impacts on fish populations \\
\hline McDonald, Lyman & $\begin{array}{l}\text { Western Ecosystems Technology } \\
\text { Inc. }\end{array}$ & Ph.D. & Biological sampling procedure, capture-recapture statistics \\
\hline Paulsen, Charlie & Paulsen Environmenal Research & Ph.D. & Statistics, fish population modeling \\
\hline Petersen, Jim & $\begin{array}{l}\text { U.S.G.S. Columbia River Research } \\
\text { Laboratory }\end{array}$ & Ph.D. & Fish biology, predation, modeling \\
\hline Pizzimenti, John & GEI Consultants & Ph.D. & Fish ecology and hydroelectric fish passage \\
\hline Pyper, Brian & Cramer Fish Sciences & Ph.D. Candidate & Biometry \\
\hline Rainey, W. Steven & GEI Consultants & P.E. & Fish passage engineering \\
\hline Schilt, Carl & $\begin{array}{l}\text { LGL Limited, Environmental } \\
\text { Research Associates }\end{array}$ & M.A. & Acoustics, fish biology, marine mammals \\
\hline Skalski, John & Skalski Statistical Services & Ph.D. & Statistics, survival studies, experimental design \\
\hline Smith, Brennan & Oak Ridge National Laboratory & Ph.D. & Hydraulics \\
\hline Tayler, Michael & Cascade Economics & Ph.D. & Economics, water rights \\
\hline Townsend, Richard & Skalski Statistical Services & M.S. & Population dynamics and modeling \\
\hline Van Holmes, Chris & Vanalyst Consulting & B.S. & Database integration and utilization \\
\hline
\end{tabular}




\subsection{Work Element 162 - Analyze/Interpret Data}

All technical products were produced by independent analysts and were subject to peer review by anonymous reviewers. It was integral to the goals of the process to maintain the independence of technical analysts by shielding them from those requesting analysis. PNNL staff worked with requestors to produce an analysis directive that could be acted upon by an analyst. The analysis directive was then assigned, without input from the requestor, to a regional expert chosen based upon the expert's stated areas of expertise. The analyst then produced a technical product that addressed the questions posed in the analysis directive. The technical product or report produced by that regional expert was then reviewed by at least two qualified technical experts.

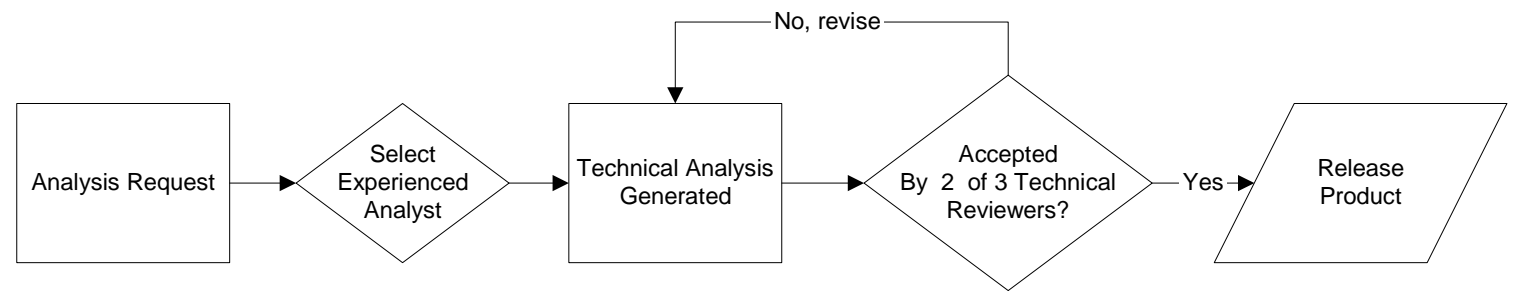

Figure 1. Data Analysis and Peer Review Process Flow[in the graphic, the B in the word "By" in the 4th step should be lower-cased]

\subsection{Work Element 119 - Project Management}

The primary objective under this work element was to define roles, responsibilities, and feedback loops for all entities involved in the ITAP project. To accomplish this, the process diagrammed in Figure 2 was developed for creating a final research report from a research question received from the web-based form[did you really develop full-blown research reports from single questions posted to a web site??]. 


\section{ITAP -- Analysis and Review Flow Chart}

(version October 2006)

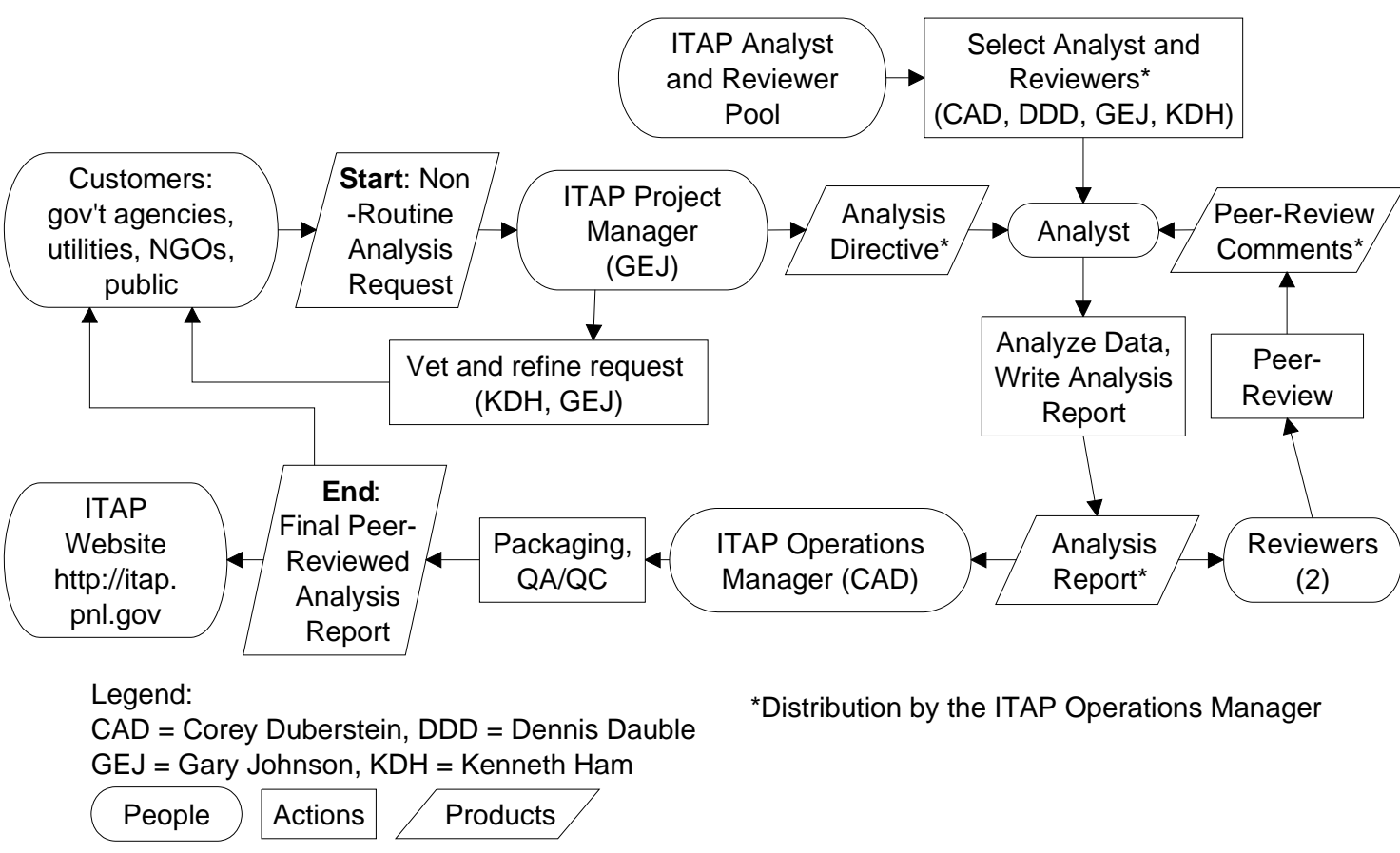

Figure 2. Roles and Responsibilities of Entities Involved in the ITAP Project

\subsection{Work Element 122 - Provide Technical Review}

Technical review within the ITAP project was accomplished by subcontracted anonymous technical reviewers. Each draft report was reviewed by at least two qualified technical reviewers. If those reviewers agreed the work addressed the analysis request and was technically correct, the product was released and distributed for use. PNNL staff did not judge the technical correctness of the analysis products. If the peer review process resulted in disagreement about an important aspect of the work, a third review was requested to resolve the issue. If at any time in the process, two reviewers found a product to be unacceptable, that product was not released until it was revised to address reviewer concerns. This rigorous review process ensured that technical products would withstand scrutiny of regional parties. PNNL project staff served as an information conduit between the analysts and reviewers to retain anonymity of the reviewers.

\subsection{Work Element 132 - Produce Annual Report}

This report to BPA fulfills the obligation of an annual report. 


\subsection{Work Element 161 - Disseminate Raw/Summary Data and Results}

It was decided that a web-based system would be used to solicit requests and deliver technical products. The ITAP website (http://itap.pnl.gov/) was developed, and a form to submit a request was incorporated. The website provided interested parties with the following information:

- a basic description of the ITAP project

- status reports of ongoing analyses

- final products in .pdf format

- a table of subcontracted expertise.

Following the final definition of the process, subcontracting of the expertise pool, and completion of the web-based request portal, PNNL advertised the ITAP project by word of mouth to prospective users and initiated contact with the Columbia Basin Bulletin (http://www.cbbulletin.com/) to advertise the existence and utility of the project.

Four requests for analyses were received:

\section{ITPAP2006_001: Influence of John Day Dam turbine unit outages in 2006 adult passage rates}

This report examined the effects of outages of turbine units 1 through 4 on passage rates of adult salmon and steelhead using the south ladder of John Day Dam during spring 2006. Although 2006 river conditions were anomalous, it was determined that adult passage was significantly lower at the south fish ladder than in previous years.

\section{ITPAP2006_002: Snake River fall Chinook salmon life history diversity}

It was recently found that many sub-yearling fall Chinook salmon do not spend their first winter in the ocean but instead overwinter within the Snake and Columbia rivers as well as the Columbia River estuary. This study tried to determine what proportion of juvenile fall Chinook salmon migrated to the ocean during their first year and what reaches were used for overwintering during the first year.

Additional questions for the study included what proportion waited until the following year to migrate?, What were the adult and jack return rates for these subpopulations?, and did the smolt-to-adult return rates of yearling migrants differ from those of subyearlings?

Only $10 \%$ of all juvenile releases could be categorized due to limitations of the data. Of these fish categorized, only 5\% did not leave the river during the winter. However, they comprised about half of the returning adults. Wild-born adults were more likely to spend their first winter in the ocean, while hatchery adults were divided equally between the two subpopulations. Hatchery-born returning jacks were more likely to be ocean-type juveniles. Most fish that left the Snake River as subyearlings were not detected the following year. 


\section{ITPAP2006_003: Juvenile salmon and steelhead survivals through the FCRPS below McNary Dam}

The original request for analysis and subsequent research directive was complex and contained a number of questions that compared survival rates of upper Columbia River, middle Columbia River, and Snake River steelhead and Chinook salmon stocks. Due to the complexity and untimely end of the ITAP project, only the first question was examined: Is survival of upper Columbia River spring Chinook salmon significantly lower than that of Snake River or Middle Columbia River stocks?. Two different methods were used to analyze existing data, and although survival rates were highly variable across weeks and/or years during the 1998-2006 time span, little evidence was found that indicated regional variation in survival between McNary and John Day dams with either hatchery or wild fish.

ITPAP2006_004: Potential for aquatic predator control to increase juvenile salmon and steelhead survivals through the FCRPS below McNary Dam

This study used bioenergetics modeling to estimate the impact of northern pikeminnow and smallmouth bass predation on juvenile salmonids in the lower Columbia River. The study also estimated the statistical power of detecting changes in predator populations or in consumption rates. It was concluded that removal of specific age classes of salmonid predators that were most prevalent in the river would have the largest effect on predation loss. However, based on the variability in existing field data sets, it would be very difficult to detect changes in predator abundance or consumptions rate without considerable field effort.

\subsection{Work Element 185 - Produce Pisces Status Report}

Periodic reporting benchmarks required by the BPA Fish and Wildlife program were met throughout the project. Previous reports were submitted within Pisces, and the finalization and transfer of this report will fulfill obligations under this work element.

\subsection{Summary of Accomplishments}

In summary, accomplishments by Project 2006-010-00 were as follows:

- Built a web-based information portal for communicating and tracking analysis requests and dissemination of technical products requesting and technical product dissemination.

- Coordinated and communicated with regional entities, including the Northwest Power and Conservation Council, Columbia Basin Fish \& Wildlife Authority, and stakeholder groups.

- Developed a pool of technical experts for analysis and peer review. 
- Demonstrated the effectiveness and scientific rigor of the ITAP concept for delivering highquality technical reports. Products included comparison of adult passage rates relative to project operations, examination of outmigration behavior and early life history, differential survival of juvenile salmon and steelhead stocks, and the potential effects of predator control on juvenile salmon survival. 